\title{
LÕUNAEESTI KEELE TAGASITULEK PROOSASSE
}

\author{
EVA VELSKER, MART VELSKER
}

\section{Sissejuhatuseks}

$\mathrm{K}$ äesolevas artiklis vaadeldakse August Kitzbergi, Jaan Lattiku, Ernst Enno ja Hermann Julius Schmalzi loomingut, eesmärk on lähemalt uurida lõunaeesti keele kasutamist nelja kirjaniku proosatekstides. Lähenemisviisi taustaks on varasemad käsitlused kirjandusteostes kasutatud murde kohta. Proosas on murret kasutatud valdavalt tegelaskõnes (vt nt Wales 2001: 106). Et aru saada, kuidas toimib fiktiivne keel tegelaskõnes, on vaja esmalt teada, kuidas toimib reaalne keel reaalses maailmas. Seega on stiiliuurimise ja fiktiivse dialoogi uurimise lähtekohtadeks ühelt poolt keeleteaduslikud lähenemisviisid (vestlusanalüüs, suhtluslingvistika, sotsiolingvistika), mida teisalt kasutatakse kirjandusteaduslikus analüüsis.

Ühe olulise kirjas edasiantud kõne ülesandena nimetavad uurijad realistlikkuse taotlust, püüet tekitada reaalse kõne illusiooni, luua tõepärane ja usutav, realistlik dialoog (Leech, Short 2007: 126, 129; Nykänen, Koivisto 2013: 21). Tegelaste keel ei saa kunagi autentset kõnet päris täpselt jäljendada, ent on võimalik ära kasutada reaalse keele variante, eristada tegelasi koha- ja sotsiaalmurrete abil, tuua keele kaudu esile tegelaste samalaadsust ja erinevust. Murdel võib seejuures eri teostes ja ka sama teose eri kontekstides olla erinevaid ülesandeid: ajastutruu kõnepruugi kujutamine, tegelaste eristamine, koomilise efekti loomine. Lisaks võivad samad keelevahendid mõjuda eri aegadel erinevalt (Tiittula, Nuolijärvi 2013: 18-19).

Dialoogi ülesanne on tõepärase maailma loomise kõrval seega ka tegelase iseloomustamine. Murret ongi sageli just selles funktsioonis kasutatud. Tavaline on murdekasutuse kaudu tegelase sotsiaalse klassi määratlemine, murre toimib kontrastis kirjakeelega ja loob mulje tegelasest, kes on harimatu ja sotsiaalses hierarhias madalal (Leech, Short 2007: 136; Nykänen, Koivisto 2013: 18). Seda on tõdenud Tiit Hennoste ka eesti kirjanduse kohta: „Murdeid ja argikeelt kasutatakse proosa tegelaskõnes ning nende ülesanne on markeerida eelkõige inimeste sotsiaalset staatust. Murdekõneleja on inimene maalt, madala haridusega ja tihtipeale just meesterahvas. Alles teises järjekorras markeerib murre inimese kindlat päritolukohta" (Hennoste 2000: 71).

Tegelast iseloomustava vahendina kasutatakse ka idiolekti, ühele isikule omaseid keelejooni, mis teda teistest eristavad. Dialekti ja idiolekti vahekorda tegelaskõnes võib iseloomustada tüpiseerimise ja individualiseerimise vahekorrana: dialekt kui keelekogukonnale ühiste joonte kogum paigutab tegelase teatavasse rühma, idiolekt tõstab tegelase rühmast esile (Leech, Short 2007: 136). Dialekti ja idiolekti suhe võib olla seejuures keerukam, kui luuakse ühtaegu samalaadse keelega tegelaste rühm ja eristatakse tegelasi selle rühma sees. Ent murde kasutamine toob esile muidki küsimusi. Sageli just madala staatuse tõttu kasutatakse murret ka koomilise efekti ja koomiliste tegelaste 
loomiseks. Leech ja Short (2007: 136-137) väidavad, et mittestandardsete keelendite kasutamine on samas stigmatiseerimise ja distantseerimise vahend, millega osutatakse tegelaste lahknevust normist, ja seetõttu on tavaline murde kasutamine koomilistel ja satiirilistel eesmärkidel.

Nagu eespool osutatud, kasutatakse murret ja kõnekeelt üldisemalt tüüpiliselt dialoogis ja otsekõnes. Otse-, kaud- ja siirdkõne vahekord ei pruugi olla siiski alati ühemõtteline ja selge. Kaudkõne kasutab jutustajateksti keelelisi vahendeid (seega murdejooni enamasti ei leia, kui tegu ei ole läbinisti murdelise tekstiga), siirdkõnes esineb nii otse- kui ka kaudkõnega, nii tegelase kui ka jutustajaga seotud jooni, niisiis võib seal esineda ka kõnekeelt. Neid küsimusi puudutatakse praeguses artiklis põgusalt, kindlasti väärivad need edaspidi põhjalikumat uurimist.

Nelja kirjaniku loomingust on praegu uurimise all tekstid, mis on ilmunud ajavahemikus 1894-1910. Esmapilgul võib tunduda autorite ja ajavahemiku valik juhuslik, kuid neil otsustel on siiski sisulised põhjused. XIX sajandi lõpul ja XX sajandi alguses taandus trükisõnast senine lõunaeesti kirjakeel ehk tartu keel (vt nt Laanekask 2004: 36-44; Tóth 2013), kuid samal ajal tekkis uue ilmega näiteid lõunaeesti keelekujude kasutamisest erinevates žanrides, keele taandumine ja tagasitulek toimusid üheaegselt. Milline vahekord on tagasituleval keelel lõunaeesti kirjakeele konventsioonidega, on omaette uurimist vääriv teema, mille selgitamine pole aga käesoleva artikli eesmärk. Võib küll tõdeda, et taanduja on väljakujunenud reeglitega kirjakeel, asemele tuleb rohkem murdelist variatiivsust. Uutmoodi keelt esineb erinevates žanrides, kuid mõistlik on proosat ja luulet analüüsida esialgu eraldi, kuna keeletarvitus on neis erinev. Lõunaeesti murrete proosasse „tagasitoojaid” on rohkem kui neli, kuid mulgikeelne Kitzberg, võrukeelne Lattik, tartukeelne Enno ja setukeelne Schmalz on nende seas kõige silmapaistvamad. Kolm kirjanikku on ka eesti kirjandusloos tuntud ning kuigi Schmalzi kuulsus on väiksem, on ta antud kontekstis kindlasti tähelepanuväärne - ta on aktiivne kirjutaja ning teda on võimalik pidada ka setukeelse kirjanduse rajajaks. Valdavalt on alljärgnevas analüüsis kasutatud tekstikujusid, mis pärinevad raamatute esmatrükkidest. Kitzbergi need jutud, mis käesoleva teema seisukohalt huvi pakuvad, hakkasid ilmuma alates 1894. aastast. Valdavalt avaldati tema proosa esimesed raamatuversioonid sarjas „Külajutud” (I-V, 1915-1921) - tõsi, jutt „Sauna-Antsu „oma” hobune” ilmus 1894. aastal „Ilmlikus Jõuluraamatus”, kuid analüüsimisel on kasutatud siiski selle teksti „Külajuttude” varianti. Lattikult on vaatluse all tema esimese raamatu „Meie noored” esmatrükk (1907). Lattik täiendas jutukogu uuema loominguga, kuid hiljem lisatud tekstid jäävad praegu vaatluse alt välja. Enno avaldas vaid ühe proosaraamatu „Minu sõbrad” (1910), mis annab siinsele käsitlusele ajalise lõpupiiri. Kuigi Schmalz alustas kirjanikuna veidi varem kui Lattik või Enno, tuleb temast eraldi juttu viimasena. Küsimus pole tema väiksemas kuulsuses, vaid selles, et ta kasutab osas oma raamatutest läbivalt kohalikku keelt - ülejäänud kolm kirjanikku päris läbivalt seda ei tee. Schmalzi esimene setukeelne raamat „Töganitsa Höödo naise võtmise ja tarõ palamise lugu” (1899) on värsivormis ja jääb praegu kõrvale, setukeelse ilukirjandusliku proosa algusotsas on viis Schmalzi raamatukest, siinse uurimuse raames pakuvad neist erilist huvi kaks varasemat: „Alatarõ Hippo Peterbuura reis ja imelik unõnägo inne toda” (1901) ja „Miä tõmokraat tähendäs?” (1906). 
Lõunaeesti keele kasutamist tollases kirjanduses on märgatud, kuid tavaliselt pole nähtust kirjanduslooliselt kontseptualiseeritud ega keeleteaduslikust vaatenurgast lähemalt analüüsitud, lähtekohti selleks on küll pakkunud mõned ülevaatlikud tööd (Hennoste 2000; Hennoste, Pajusalu 2009; Velsker 2015). Käesoleva artikli autorite arvates tuleks märgata, et lõunaeesti murrete „uutmoodi” tulek kirjandusse pole juhuslik komplekt üksikjuhtumeid, vaid kollektiivne fenomen, mis just XIX ja XX sajandi vahetusel muutub omamoodi laineks, sel ajal ilmunud tekstid panevad aluse murrete kasutamise printsiipidele hilisemas eesti kirjanduses. Murret kasutatakse teadlikult, seega on tegemist millegi enamaga kui kirjaniku lapsepõlvekeele mõjudega eesti kirjakeeles. Õieti on põhjust kõnelda laiemalt murrete kasutamisest, XIX sajandi viimasest veerandist leiab näiteid ka mujalt kui Lõuna-Eestist. Lisaks lõunaeesti murretele paistab silma saarte murde ja idamurde kasutamine proosas, näiteks Juhan Liivi jutud „Pildikene Peipsi rannalt”, „Juak” ja „Vari”. Lõunaeesti murretel on siin ometi mitmel põhjusel eriline koht. Milline tekst on tekkivas laines kõige esimene, on raske öelda. Kindel on see, et üks varasemaid on Juhan Kunderi „Holstre keele murdes” kirjutatud „Orst” (raamatuversioonis „Or'st ehk Sults-Matsi ja Kommesnööri veider kohtulugu”, 1903). See ilmus ajalehes Valgus postuumselt 1893. aastal, algmaterjal on aga pärit 1874. aastast (Laigna 1959: 74). Tegemist on naljalooga, kus lõunaeesti keel esineb nii dialoogides kui ka jutustaja keeles. Kunderi otsemõjust setukeelsetele naljajuttudele pole midagi teada, kuid laias laastus on tegemist samasuguse lahendusega. Setukeelsed tekstid hakkasid levima sajandivahetusel ja sellest kujunes murdelise proosa laine väike omaette lisalaine. „Seturaamatute" esikirjanikuks kujunes Schmalz, aga eraldi raamatutena ilmusid näiteks ka Peeter Friedrich Kõivu „Kuis Kärekülä seto Pihkvah jesätse kassi prohvusõ peräst parki saasõ” (1902) ja Jaan Vahtra „Setu nali” (1905).

Proosas kujuneb sel ajal tüüpilisemaks see, et murret kasutatakse tekstis siiski vaid osaliselt. Kitzberg on nende lahenduste läbiproovimisel teenäitaja positsioonis, Lattik ja Enno natuke nooremate meestena saavad juba senisele praktikale toetuda ning seda edasi kujundada. Neid kujundajaid on veel, vaadeldavast ajavahemikust näiteks Villem Buk (Buck) oma jutuga „Abi” (kogust „Kolm suurt muret”, 1909) või Mait Metsanurk oma esimese romaaniga „Vahesaare Villem” (1909). Metsanurga dialoogides kasutatud Põhja-Tartumaa keel pole küll rangelt võttes lõunaeesti keel, kuid tegemist on siiski keskmurde kõige kagupoolsema variandiga.

\section{August Kitzberg}

August Kitzberg sündis Laatre külas Halliste murraku alal, hiljem on elanud ta ka mujal Mulgimaal ning kaugemalgi. Kitzberg on tuntud keeletundliku autorina, tema mitmesuguste keelekujude jäljendamist nii proosa-, draamakui ka värsiloomingus on näiteks toodud korduvalt, kõige tuntum on ehk kadakasakslik eesti-saksa segakeel. Ka mulgi autorina on Kitzberg rõhukalt esil, aga seejuures on murdekeelt teostes kasutatud isegi vähem, kui oodata võiks. Et kohaliku keele ja kirjakeele vastuolulist suhet teadvustas Kitzberg isegi, seda ilmestab lõik „Püve Peetri „riugaste”” algusest: „Ja siis veel tulevad nad ja nõuavad: kirjuta selget Eesti keelt, hoia end kohaliste kõnekäänude eest, 
mida igal pool Eestis ei tunta! Mingu nüüd ja tehku jutukirjutaja vaenekene, just kui külarahvas kirjakeelt kõneleks!" (Kitzberg 1920: 7)

Siin on vastuolu selgelt esile toodud: jutustajale on teada, et külarahvas räägib murret, samas on selged ka lugeja ootused. Ühtlasi võib märgata sedagi, et tähelepanu pööratakse nimelt külarahva kõnelemisele, jutustajatekstis seega murret eriti ei oodatagi. „Püve Peetri „riugastes”” on kimbatus lahendatud nii, et neutraalseks keeleks on kirjakeel, seda ka otsekõnes. Kitzbergi valik on seega kasutada jutustajatekstis kirjakeelt, murre on võimalik otsekõnes, jutustajatekstis võivad esineda murdelised tsitaadid.

Mis põhjustel siis Kitzberg murret kasutab? Ühe võimalusena koha ja kohaliku keele markeerimiseks. Seda eesmärki teenivad eelkõige jutustajateksti põimitud tsitaadid, aga näiteks „Püve Peetri „riugastes”” ka otsekõne, mis ei iseloomusta üht konkreetset tegelast, vaid on antud omamoodi üldistusena: „Tuli õnnis laupäeva õhtukene, kallis videviku ajakene, juhtus Hans Jürile ehk Jüri Jaanile tänaval vastu - kohe oli küsimine lahti: „Koes sia täempe lääd?” „Sinnasamas iki.” „Koe sinnasamas?” „Mia lubasi püvesid pillitem’ minnä.” „Mia tule kah, lääme!”" (Kitzberg 1920: 13-14)

Murdega ei iseloomustata siin mitte konkreetset tegelast, vaid külapoisse üldse, viisi, „kuidas siin räägitakse”. See lõik jääbki tekstis ainsaks mulgikeelseks dialoogiks. Tegelaste kõne on edaspidi antud kirjakeeles, leidub vaid üks Jalaka Jaani lause: „Massikandja om puha sõkelpüksi” (Kitzberg 1920: 26), aga seegi ei ole antud dialoogis, vaid tsitaadina jutustajateksti sees, viitena kohalikule keelepruugile.

Murre konkreetse tegelase kõnes võib küll eraldi osutada päritolule, aga sel juhul ei ole enamasti tegu mulgi keelega. Mulgimaa olustikus liikuvatele tegelastele on neutraalse keelena antud kirjakeel, murdekeelega markeeritakse aga mujalt pärit tegelasi, kõige tuntumaks näiteks ilmselt Saaremaa Priidu „Püve Peetri „riugastes”". Saarte murre kui mitme joone poolest selgelt eristuv keelevariant on olnud kirjanduses lõunaeesti murrete kõrval sagedamini kasutatavaid murdeid (Hennoste, Pajusalu 2009: 120). Selle kõrval kasutab Kitzberg päritolule osutamiseks teisigi keelevariante: nii on näiteks jutustuses „Hennu veli” koolivanem pärit Surjust ja räägib „kanget Surju murrakut" (Kitzberg 1915: 129), mille markeerimiseks on kasutatud läänemurde jooni.

Kirjakeelses dialoogis võib leida aga Mulgi murde kerget markeerimist, mõned Mulgi murde jooned on antud näiteks Nõuni Jaagule jutustustes „Veli Henn” ja „Hennu veli”. Keelejooned on tegelaskuju iseloomustamiseks valitud tabavalt: pöördumisena kasutab Jaak pidevalt vormi latsekene, toob seega kirjakeelsesse teksti lõunaeestilise varjundi, samas on oluline ka deminutiivsus. Ühe iseloomuliku mulgi joonena kasutab Nõuni Jaak deminutiivsufiksiga soovkõne vormi, näiteks: „Võtakst nüüd, poeg, noot ja tõsta lootsikusse” (Kitzberg 1915: 33). Valitud keelejooned aitavad ühelt poolt rõhutada Jaagu isalikku ja lepitavat loomust, teisalt aga ka alalhoidlikkust ja vanapärasust.

Murde kasutamine dialoogis läbivalt, mitte ainult üksikjoontena, ongi Kitzbergil üks võimalusi vanuse või sotsiaalse staatuse märkimiseks. Lisaks vanainimestele on murdelisi repliike ka lastel, näiteks karjalaps loos „Rahvuslik": "Mia ei sa tat puhtes," vastab see ja näitab teelusikat. „Tää, mis mia tal pia tegeme!”” (Kitzberg 1919: 92) või „Hennu velje” mälestusliku osa üksikud lapse repliigid. Tekib teatav kontrast, vastandus, vanuse, hariduse, sotsiaalse staatuse põhjal. Sellisena on seda kasutatud koomilise efekti tekitamiseks 
(mis on tüüpilisi murdekasutuse jooni, nagu eespool osutatud). Nii näiteks on „Hennu veljes” selgelt vastandatud kaks naist, „lagunud suuga” (Kitzberg 1915: 128) naine murdekeelsete repliikidega ning minajutustaja lepitav ema, kelle kõne on antud kirjakeelsena. Seejuures võib vaikimisi eeldada, et siingi on kasutatud sama võtet: neutraalne kõne on esitatud kirjakeeles, seda, et tegelikult räägitakse siiski Mulgi murret, on markeeritud üksikute repliikidega, mis ei ole pandud ühegi konkreetse tegelase suhu: „....sest ega koolmeistrile ei võinud vastata „Mia ei tää!”” (Kitzberg 1915: 119). Konkreetse tegelaskuju kõnepruugis omandab murre sageli koomilise varjundi, oluline on seejuures tegelase sotsiaalne staatus, haridus. Toimib vastandus, ent koomilises võtmes võib vastandus ka kaduda, kui tegelased keele abil ühele pulgale seatakse. Näiteks on „Hennu veljes” esitatud lugu, kus vana härra vestleb surivoodil Täksiga mulgi keeles, keelt on seejuures rõhutatud ka jutustajatekstis: „vana õnnis rääkis ju pehmet, meie oma nurga murrakut” (Kitzberg 1915: 150).

Keelekoomika on Kitzbergile kindlasti oluline, nagu osutatud, võib koomilise efekti tekitada ka Mulgi murde kasutamine, aga murre ei tekita tingimata automaatselt koomilist efekti, koomilisus tuleb esile eelkõige vastandustes (haritud - harimatu, laps - täiskasvanu). Teine Kitzbergile väga iseloomulik võte on keelte segamine: juttudes esineb eesti-saksa, eesti-vene, eesti-läti segakeelt. Makaroonilise stiilina on seda käsitlenud Maie Kalda, osutades niihästi makarooniliste dialoogide ideoloogilisele eesmärgistatusele kui ka superstraatkeelte rohkusele (Kalda 1996: 264). Mulgi keelt segab muude keeltega „Veli Hennu” Beersing, kes jutustaja sõnul „oli selle poolest iseäralik mees ja õieti uue aja iseloomu algkuju, et tema enese kuus keelt ütles rääkivat, aga ühtainustki neist ei mõistnud" (Kitzberg 1915: 39).

Ent Kitzbergi teostes on võimalik ka murdekeelse dialoogiga tõsine tekst. Eriti selgelt tuleb see esile jutus „Sauna-Antsu „oma” hobune”. Jutustajatekst on läbivalt kirjakeelne, dialoog läbivalt mulgikeelne. Siingi on oma osa tegelaste sotsiaalsel staatusel, kõik kolm tegelast on vanad ja madala sotsiaalse staatusega, ent murdekeelt ei kasutata karikeerimiseks ega humoorikuse saavutamiseks. Teema, tekst ja dialoogid on tõsised, ja kui siin muuhulgas õrnkurba huumorit leidub, siis pole see siiski murdekasutuse tulemus. Seesugune lahendus toimib aga siis, kui puudub vastandus ning kõik tegelased on enam-vähem võrdsel positsioonil. Nii näiteks on samamoodi tõsises jutustuses „Räime-Reeda 10 kopikat” dialoog läbinisti kirjakeelne: siin suhtlevad erineva sotsiaalse seisundiga tegelased ja sel puhul mõjuks murre tegelase suus paratamatult koomiliselt või madaldavalt. Märkida tasub ka seda, et murre on kasutusel ikkagi vaid otsekõnes, tegelase sisemonoloogid on kirjakeelsed, isegi siis, kui mõttes toimub kujutluslik dialoog. Seesugune kasutus tuleb ilmsiks ka teiste autorite teostes.

Kitzbergi tekstides on murret niisiis kasutatud mitmel viisil ja ka eri juttudes erinevalt: kohalikkuse osutamiseks, koomika ja vastanduste loomiseks, tegelaste sotsiaalse seisundi markeerimiseks. Kitzbergile on omane keelekasutuse reflekteerimine, mitmes teoses on osutatud kasutatud keelele, seega võib arvata, et valikud on teostes tehtud teadlikult. 


\section{Jaan Lattik}

Jaan Lattik esindab proosas murdekasutuse klassikalisi lahendusi - neid, mis saavad üldiseks tavaks XX sajandi eesti kirjanduses. Traditsioonid olid kujunemas küll juba enne teda, kuid Lattik teeb Kitzbergi keelelisest mitmekesisusest loogilise valiku, jätab osa võimalusi kõrvale ja muudab ülejäänu reeglipärasemaks. Siit ei tule mõistagi otsida väidet, nagu Lattik oleks teadlikult õppinud kirjutamist Kitzbergi tekste uurides. Võib arvata, et murdekasutuse küsimus oli tahes-tahtmata õhus ning seda õhustikku oli seni Kitzberg oluliselt mõjutanud. Ega Lattikugi tekstid esinda kivistunud süsteemsust - reeglipärasuse kirjeldamisel tuleb teha reservatsioone ning tõdeda erandite olemasolu.

Lattiku „Meie noorte” esimesel leheküljel annab joonealune osutus teada, et kasutusel on „Võru-Karula murrak” (Lattik 1907: 5), niisiis on ta kasutanud omaenda lapsepõlvekeelt. Ootuspäraselt on võru keelt näha osa tegelaste otsekõnes ja jutustajatekst on samas eestikeelne. Lattik kirjutab muhedaid lugusid lastest ja need lood sisaldavad ka hõllanduslikku mälestuslikkust. Tavaliselt (kuigi mitte alati) räägivad lapstegelased Karula murrakut. Selle tarvituse ühtlases murdepärasuses pole põhjust kahelda ja samas on seda nii Lattiku kui ka teiste autorite puhul raske lõplikult hinnata - küsimus pole ainult kirjaniku keeleoskuses, vaid ka selles, kuidas tekst on kirja pandud. Ortograafilistele probleemidele ja näiteks ka sellele, et Lattik polnud vokaalharmoonia märkimises päris järjekindel, on hiljem tähelepanu juhitud seoses tema proosa taasavaldamisega - uus jutukogu tõi omakorda kaasa uusi toimetamisalaseid küsitavusi (Saar 1998).

Lattiku tegelaste keel on selgelt seotud hariduse ja sotsiaalse staatusega, kaasa mängib ka päritolu. Seda ei ole küll enamasti vaja rõhutada, kuna tegelaskond on päritolult homogeensem kui Kitzbergil ja keelte ristamisi tuleb vähem ette. Siiski saame jutus „Kui meil veel püksa ei olnud” otsesõnu teada, et Tädi-Karlaks kutsutud poiss kasutab segamini Tartu ja Võru murret (Lattik 1907: 15). Koolis käinud täiskasvanud tegelased on tavaliselt pandud rääkima eesti kirjakeelt. Iseloomulik on lapse ja täiskasvanu dialoogina ülesehitatud jutt „Esimene armastus”, kus laps on järjekindlalt lõunaeestikeelne, täiskasvanu aga põhjaeestikeelne. Täiskasvanu on mitmes mõttes „kõrgemal” positsioonil ning sedasi tekib ka jutustajatekstis sagedasti ülalt alla suhe oma tegelastega. Hierarhilisus on loodud humoristliku leebusega, jutustajahääl on kaastundlik, aga ikkagi üleolev. Lattiku juttude üks püsivamaid teemasid ongi täiskasvanute ja laste maailmade kohtumine, esimese jutu „Noorte soovid” esimest lauset saab lugeda kui sissejuhatust sellesse teemasse: „,Kusti, mis sa inele ostad, ku sa suures saad," küsis Värdi” (Lattik 1907: 5). Suurte ja väikeste inimeste maailmade kohtumises on koomikat, mis avaneb täielikult vaid täiskasvanu pilgu läbi ja avaldub ka keelelise suhtena. Tihti on Lattiku lühiproosat nimetatud lastekirjanduseks - õigem oleks siiski rääkida kahese adressaadiga loomingust, nagu seda mõnikord ongi tehtud (nt Mattheus 2015: 106).

Lattiku proosas on küll ka mõni täiskasvanud tegelane, kes on pandud kõnelema võru keelt, näiteks jutus „Imä õe!”. Sellisel juhul asub tegelane jutustajapositsioonist selgemini lahus, tegevust vaadatakse rohkem kõrvalt. Küsimus, miks mõnes jutus on lapstegelased pandud rääkima eesti kirjakeelt, on pealtnäha keerulisem, kuid siin paistab olevat konkreetne seletus: Latti- 
ku võru keelel on küll realistlikke eesmärke, aga see on ühtlasi ka naljakate tekstide keel. Erinevused tulevad välja juba pealkirjadeski: jutus „Imä õe!” pöördub laps ema poole võru keeles ja tekst on naljakas, jutus „Ema ära karda" on pöördumine eestikeelne ja lugu on tunduvalt tõsisem. Väike tunnustav muie lapse täiskasvanuliku käitumise üle selles loos siiski peitub ja siin on ka üks pooleldi võrukeelne repliik: minategelane koputab uksele ja laps küsib: „Kes sääl om?” (Lattik 1907: 44). Rohkem võru keelt tekstis pole, edasine on üles ehitatud nii, et lapselt otsekui võetakse hääl ära. Minategelane pöördub korduvalt lapse poole, aga otseseid vastuseid ta ei saa, vastused tulevad ema seletuste ja ümberjutustustena. Kui selles loos ikkagi esineb väike muie, siis muie on täiesti kadunud sellistes juttudes nagu „Juku” ja „Kiri” - see tähendab ühtlasi, et kadunud on kohalik keel ja lapstegelase otsekõnes võru keelt ei kasutata.

Nii nagu Kitzbergil, esineb ka Lattikul jutustajakõnes murdelisi tsitaate. On näha, et erinevad kirjanikud kohtuvad samalaadse probleemiga ja lahendavad selle ka enam-vähem samamoodi. Jutustajatekstis läbivalt murde kasutamine mõjuks radikaalsena ja see tekitaks vastuolu tüüpiliste keeleideoloogiliste seisukohtadega. Samas on Lattikul soov edasi anda tegelikku keeletarvitust ning luua muhedat atmosfääri. Sagedasti tuleb seda võtet ette näiteks jutus „Kui meil veel püksa ei olnud”, kus see Lattiku stiili ühe olulise komponendina teiste võtetega haakub. Näiteks nii: „Kui ma jutustamisega selle koha juurde jõudsin, kus Simson kolmtuhat rebast kinni püüdis, neile tule „hanna alla” tegi, ja sedaviisi „Viljandi” meeste viljasaagi sootumaks ära hävitas, siis põlesivad Küla-Kaarli ja Tädi-Karla silmad just nagu ülekohtuste Viljandimaa meeste vilja rõugud. Antsgi, kellel muidu suurt huvitust juttude vastu ei olnud, näitas ühtelugu metsa poole ja kisendas kurja häälega: „Lepän, lepän!"” (Lattik 1907: 16-17) Tsiteeritud lõigu algusosas pole otsekõnet. Seda, et tegelikult käib jutt võru keeles, peab lugejale meelde tuletama tsitaadina esitatud „hanna alla”. Jutustatakse piiblilugu (vrd Km 15), jutustamise käigus on kolmesajast rebasest saanud kolm tuhat ja vilistitest Viljandimaa mehed. Lõpuks tuleb ka võrukeelne otsekõne, aga sellesse on lisatud veelgi nalja, sest siin kõnelev poiss ei oska hääldada $r$-tähte ning võrukeelne sõna repän muutub otsekõnes lastekeelseks.

Vahekokkuvõtteks Lattiku lahendustest võib öelda, et siin on näha vähemalt nelja kõige klassikalisemat tunnusjoont: esiteks - murret kasutatakse valdavalt otsekõnes, teiseks - murret kasutatakse mõnikord ka tsitaatidena eestikeelses tekstis, kolmandaks - murre märgib sotsiaalset staatust, haridust ja päritolu ning neljandaks - murre seostub mälestusliku hoiakuga. Lisaks neile joontele on kindlasti väga iseloomulik see, et lõunaeesti keel on koomilise teksti keel, olgugi et mitte kõik edaspidised eesti murdejutud pole humoristlikud.

\section{Ernst Enno}

Ernst Enno sünnikoht Valguta asub Rannu ja Rõngu kihelkonna piiril, tema kodukeeleks on peetud Rõngu murrakut (Peebo 2006: 266). Raamat „Minu sõbrad" paigutub autori lapsepõlvemaastikku, lugudel on mälestuslik taust. Mälestuslikkust ja murdekeelt märgitakse ära omaaegses retseptsioonis, pea kõik arvustajad kõrvutavad Enno teost Lattiku omaga (Grünthal 1910; Hubel 
1910; Kitzberg 1910: 462; Tuglas 1911: 36). Kõige põhjalikuma arvustuse on kirjutanud Tuglas, kes „kunstilise mõõdupuuga” hinnates teost väga väärtuslikuks ei pea. Küll aga toob ta „meeldiva” joonena esile nii Enno kui ka Lattiku juttudes murde kasutamise. Tõsi, kiituse võtab ta kohe poolenisti tagasi, öeldes, et „kahjuks on Lattika ning Enno murretel vähe neid elementisid, mis nad kirjakeelele jäädavaks lisanduseks anda võiksivad”, mõlema keeles näeb ta teatavat koomilisust ja koguni karikeerimist ning võrdleb neid ka „seturaamatute" kirjutajatega (Tuglas 1911: 36).

Enno murdekasutuses ilmnevad needsamad põhijooned: murre on kasutusel valdavalt otsekõnes, kirjakeelses dialoogis võidakse kohalikkust mõne tunnuse abil markeerida, jutustajakõnes kasutatakse murdekeelseid tsitaate, keelevalikut mõjutab haridus ja selle kaudu sotsiaalne staatus, ehkki see ei ole nii selge kui eespool käsitletud autoritel. Ent selle kõrval võib täheldada eristuvaid jooni. Murre ei ole Ennol koomika keel, erinevalt Lattikust. Tuglas arvas teisiti, kuid tema arvamust võis mõjutada üldisem tendents kasutada murret naljajuttudes ning tõsi on ju ka see, et Enno pole alati surmtõsine. Enno juttudes võib nalja küll saada, ent seda ei tekita keelekasutus, tartu keeles saab rääkida tõsiselt ja tõsistest asjadest. Teise olulise joonena torkab silma, et Ennol on tartu keel ka sipelgate ja lindude keel: „...et sipelgad neid oma pesasse vedada ei taha, nina kärsutavad ja ütlevad: neo om ju nuu va äränõijutu kadaja pinnu, meie noid omale pessä ei taha; noide peräst võise kuldne päike meie pääle vihatses saia ja tuul kõik puuossa meie pääle pildu, et meist jälgegi järgi ei jää.” (Enno 1910: 25-26) Seda väidet avardades võib ühtlasi väita, et tartu keel on sügavamate tunnete, vahetute kogemuste keel, selles keeles räägivad ka asjad ning tartu keel tuleb spontaansete hüüatuste ja ütlustena ka kirjakeelse teksti sisse. Kindlasti mõjutab tunnete ja meeleolude esitamist murdes mälestuslikkus, ühtlasi võib oletada käsitletud autorite hulgas kõige enam prototüübi keelekasutuse mõju. Enno mälestuslikud jutud võivad tunduda tema müstilise luule kõrval maised ja konkreetsed, kuid seda elutunnetust, mida on näha luules, leiab ka proosas. Maailm, kus kõik olendid ja asjad kõnelevad, on kindlasti ennolik. Seda kõnelemist on võimalik siduda tema huviga budismi ja teosoofia vastu. Eriti ilmekas on selles suhtes lõpulugu „Veli Joonatan”, kus Joonatani lummab „riivehmerde ködsin” 'reeaisade kägin', mille kõla kutsub Köödsä kõrtsi, aga mis on tema jaoks ka valguse allika otsimisega seostuv orjahingede laul: „Tu om, mes tiid vällä otsib” (Enno 1910: 111).

„Minu sõprades” kõnelevad tegelased üldjuhul ühte keelt ja enamasti on selleks tartu keel, vaid esimeses jutus on dialoog valdavalt kirjakeelne. Sellegi taustaks võib pidada tegelastele võrdse positsiooni andmist: minajutustaja peamine vestluspartner on juudi poiss Jankel, kelle keelt oletamisi võib pidada minategelase omast erinevaks. Võrdsel positsioonil suhtlejatena on neutraalseks keeleks tekstis tartu keel, seda ka minategelase isa ja ema suus. Seejuures on kirjakeeles murdelisust markeeritud näiteks artiklilaadselt kasutatud pronoomeniga too: „Kunas to viimne päev siis tuleb?” (Enno 1910: 12). Seda keelejoont on kasutatud korduvalt, lisaks murdelisusele markeerib see hästi ka üldist kõnekeelsust. Samuti on tsitaadina jutustajateksti põimitud murdekeelne lause ema suust, dialoogides on ema repliigid kirjakeelsed.

Samas jutus tuleb murre ilmekalt esile ka spontaansuse, tunnete ja looduse keelena, näiteks jutu lõpus muidu kirjakeelse teksti sees minajutustaja hüüatus „Jankel tu es ole!” (Enno 1910: 22). Samal kujul kordub hüüatus 
tegelase sisekõnena, kolmandal korral, jutustajatekstina on see esitatud kirjakeelsena („Jankel see ei olnud!”). Seda võib tõlgendada spontaanse, „hinge sügavusest" tuleva hüüatusena, millele pakub ka selles jutus paralleeli tartukeelne lindude kõne.

Teistes juttudes on dialoogid valdavalt tartukeelsed, kirjakeelsed repliigid on antud minategelasele loos „Saare vana”. Siin korreleerub keelekasutus minajutustaja muutunud eluga: kui teistes lugudes on minategelase dialoogid esitatud lapse positsioonilt, siis selles loos on Saare vana vestluspartneriks Riias õppiv noormees. Seesuguse kakskeelse dialoogina võiks olla tegu üsna loomuliku suhtlussituatsiooniga. Ent selleski dialoogis toimub ühes kohas üleminek tartu keelele, üks repliik vastuseks Saare vana küsimusele on kaunis tartu keeles. Samas tundub seegi suhtlussituatsiooni arvestades loomulikuna, peegeldades olukorda, kus mujal kirjakeelt kõnelev inimene emakeelses keskkonnas keeli vahetab.

Enno teoses on niisiis Tartu murre kasutusel loomuliku keelena, seda ei kasutata koomilise efekti tekitamiseks, see ei markeeri ka sotsiaalset staatust niisama selgelt kui teistel kirjanikel. Enamasti on tegelastele antud sama keel, sotsiaalsest staatusest olenemata, ja enamasti on see tartu keel. Seetõttu on võimalik keelt vastavalt tegelasele varieerida, nii et määravaks ei saa mitte murre iseenesest, vaid see, kuidas murret räägitakse. Näiteks iseloomustavad Roesu Jürit rohked partiklid ja kordused: „Kae, kui tules sõda, iks sõda jah. Siss kui sõda sõdis, iks sõdis jah. Kui siss tulessiva pargiajaja, iks tulessiva jah, ja võtassiva kõik tüdruku, iks võtassiva kõik tüdruku..." (Enno 1910: 49-50). Saare vana kõne on antud lühikeste lausete ja fraasidena, dialoogis on vastused napid fraasid („noh iks”, „niisammuti iks”). Nagu jutustajatekstis iseloomustatud: „Tao kui räni: ainult mõned sädemed” (Enno 1910: 70). Seega on tegelast karakteriseeriva vahendina olulisem idiolekti tasand.

Loomulikule keelele lähendab kasutatud keelt ka varieerumine, mida tekstides täheldada võib. Häälduslikku varieeruvust ei ole üldiselt eriti lõunaeesti keele puhul võimalik täie kindlusega järeldada (erinevad tavad, eriti vokaalharmoonia märkimisel on võimalikud ka lihtsalt vead), morfoloogilist varieerumist on kergem tuvastada. "Veli Joonatanis” esineb olevikus ainsuse 3. pöördes tüüpilise $s$-lõpulise oleviku kõrval ka $b$-lõpp, näiteks „va vellekese maja küll palas”, „tare palab” (Enno 1910: 102, 103). Rõngu murrakus esineb tõepoolest ka $p$-lõpulist olevikku, mis on tõenäoliselt eesti kirjakeele mõjul trükitud $b$-lisena.

Enno juttude kohta saab kokkuvõtteks tõdeda, et siin on küll traditsioonilisteks kujunevaid võtteid (näiteks murde kasutamine otsekõnes), aga samas eristuvad need ikkagi mitme tunnuse poolest. Enno tekstid on sageli tõsised ning ühe ja sama murde piires antakse tegelastele erinev keel - kui nii, siis võib väita, et Enno lõunaeesti keel toimib normaalse keele kombel rohkem kui teiste kirjanike murdekasutus. See kõik tähendab ühtlasi tegelastele võrdsete positsioonide andmist, mis peegeldub ka keeles. Raamatu pealkiri „Minu sõbrad" asetab tegelased võrdsele tasapinnale, samas kui näiteks Lattiku täiskasvanulikult valitud pealkiri „Meie noored” sisaldab endas teistsugust suhet. 
Hermann Julius Schmalzi proosa erineb esmapilgul põhimõtteliselt seni arutuse all olnud tekstidest. Lähemalt uurides siiski selgub, et tal on teiste kirjanikega märgatav ühisosa, kuigi peamine tõsiasi jääb teda eristama - ta ei kasuta oma juttudes eesti kirjakeelt. Schmalz sündis Räpina kihelkonnas Setumaa piiri lähedal ja oli lõunaeestlane, kuid mitte setu. Kas Schmalzi juttude keel on pigem setu- või võrupärane, vajab veel üksikasjalikumat uurimist, kuid mõni tähelepanek murdepärasuse asjus on siiski kohe võimalik. On ilmne, et kirjapildis ei pruugigi Räpina murraku ja setu keele erinevused olla väga suured, ning samuti on ilmne, et Schmalz püüab tekstis setupärasust rõhutada. Ta kasutab tähti bl ja $z$, mis lahknevad eesti õigekirjast, kuid mis on olnud setu keele ülesmärkimisel ka mujal kasutusel. Vahur Aabramsi arvates hakkab eriti kirillitsast pärit bı tööle omamoodi meeldetuletusena, et loetakse midagi „võõrast” (Aabrams 2013: 171). Tundub, et selline meeldetuletav-rõhutav ülesanne on ka mõne keelevormi sagedasel kasutamisel, kuigi võib arvata, et Schmalz kirjutas spontaanselt ega mõelnud liiga palju vormide õigsuse või funktsioonide üle. Üks sõna, mille „ülekasutamist” setupärasuse markeerimise eesmärgil võib kahtlustada, on diskursusepartikkel vet 'eks, ju'. Schmalzi esimese proosaloo algus on selline: „Vet igäüts kes minno nännü oo, tiid ja näge, et mul puult nonna ja katõ päälmist hammast puudus oo, - a' tuud kuis ma näist ilma jäi ei tiiä kiäki; tuuperäst sbls kõnõlõ ma kblgõ päält tuu luu är': „Vet olli ma poiskõsõ zura, aasta katõtõskümne vanu, ku tei ütskõrd üte väiko kiiga, vai nigu maarahvas ütlese: viiole"." (Schmalz 1901: 3) Lisaks sõnale vet äratab siin tähelepanu verbivorm oo 'on', mis on iseloomulik läänepoolsetele murretele, aga mida lõunaeesti murrete aladel peaaegu ei esine. Saareste „Väikeses eesti murdeatlases” (Saareste 1955: 66) on oo märgitud Karksi murraku alale, sedagi vormina, mida esineb vaid vähesel määral vanemas keeles ja mäletamisi. Samas on kindel, et eestikeelseid tekste lugema harjunud inimese silmis paistab oo olevat tugevalt murdeline. Tsiteeritud lõigu lõpust jääb mulje, et kahest paralleelselt samas tähenduses kasutusel olnud sõnast kiik ja viiol 'viiul' on murdelisem viimane. Toodud näite najal võib siis esialgu oletada, et setu keelele iseloomulikke jooni püüab Schmalz tugevalt rõhutada, kuid see õnnestub tal vahelduva eduga. Samas ei tohiks olla Schmalzi kasutatav keel midagi arusaamatut ei lugemisoskusega setudele ega ka võrukestele.

Siit kasvab välja Schmalzi tekstide adressaadi küsimus. Kui Lattiku juures sai mainitud „kahese adressaadiga loomingut”, siis seda saab teha ka siin, kuigi teises mõttes. Schmalz kehastub oma raamatutes ka proosategelaseks, setude sõbraks, kes on setudele teada ka „Töganitsa Höödö” autorina (Schmalz 1901: 25). Ühes hilisemas Schmalzi raamatus kohtuvad kaks setut Tartus, räägivad Töganitsa Höödo loost ja üks meestest kinnitab innukalt: „Mul umava inämbiste nu tõõsõ raamadu ka kbik, miä mii keeleh vällä om anto, kotoh. Tõganitsa Höödo om, Alatarõ Hippo om, Sus om tuu tõmokraadi raamat ka.” (Schmalz 1912: 15) Schmalz esitleb end seega setudele kirjutava kirjanikuna, kuid on kahtlane, kui palju setudest lugejaid XX sajandi alguses üldse leidus. Aabrams on tähelepanu juhtinud selleaegsete setude madalale kirjaoskusele ja ka sõnaseletuste esitamisele raamatutes ning leidnud siis loogiliselt, et Schmalzi juttude ideaalse lugejana võiks ette kujutada pigem eesti kirjakeelt valdavat võrukest (Aabrams 2013: 172). 
„Miä rohkõmb lolli tükkä, toda ilosamb jutt,” ütleb seturaamatute autor tegelasena esimeses loos (Schmalz 1901: 26). Kui kirjanik ja lugejad ei kuulu setu kogukonda ja tegemist on naljajuttudega, kus peab olema võimalikult palju „lolli tükkä”, siis tekib küsimus, kas need on raamatud, kus tehakse setude üle nalja. Mingis mõttes nii ongi, kuigi nali ei ole pahatahtlik ja autori enesepeegeldus setude sõbrana on tõenäoliselt siiras ning ka jutustamine on teatavas mõttes demokraatlik. Schmalzi värvikamad jutud (nende hulgas kõnealused kaks) on lood, kus setud kohtuvad millegi ja kellegi võõraga, need kohtumised kukuvad halvasti välja ja sellelt pinnalt tekib koomika. Alatarõ Hippo satub Tartusse ja ta röövitakse paljaks, jutus „Miä tõmokraat tähendäs?" saab setu Pärnumaal kolmkümmend hoopi ihunuhtlust. Mõlemal juhul on peategelase rumalusel oma osa sündmuste käigus. Keeleliselt need kohtumised võõraga päris ootuspäraselt ei kajastu, ka Tartu ja Pärnumaa inimesed on raamatutes pandud kõnelema peategelaste keelele sarnast setu keelt. Kuigi eesti kirjakeel siin kaasa mängima ei hakka, eristuvad siiski teised keeled. Mõlemas kõnealuses jutus esineb näiteks vene keelt ja mõlemal juhul tuleb ette ka vene ja setu keele segamist samasuguse lustakusega, nagu seda võis leida Kitzbergil. Makaroonilist stiili on muudeski Schmalzi tekstides (ka poolsaksa keelega mängimist) ning sellele tahule on pühendatud ka suur osa Aabramsi saatesõnast Schmalzi juttude uustrükile (Aabrams 2013).

Mõlemat siin vaatluse all olevat juttu on võimalik tõlgendada ka kui eksituste komöödiat, mis tekib võõra sõnaga kohtumisel: esimeses jutus laheneks asi teisiti, kui Hippo teaks, kus Tartu linnas asub tõlõkraat 'telegraaf', teises jutus kohtutakse sõnaga tõmokraat 'demokraat', mida minategelane käsib meeles pidada naisel, kellel läheb meelest, kas see sõna oli „tbınõkraat vai tıımõkraat" (Schmalz 1906: 11), lõpuks aga selgub, et ei piisa õigetest sõnadest, vaid ka sõnade tähendusest tuleb õigesti aru saada.

Kuigi Schmalzi murdekasutus tegelaste otsekõnes ei avaldu samamoodi kui näiteks Lattikul, on siiski seos olemas. Ka Schmalzi murdekasutuses domineerib tegelase hääl ning seda aitavad rõhutada mitu tegurit: ühelt poolt tekstide rõhutatud dialoogilisus, teiselt poolt see, et minavormis jutustaja positsioon ühildatakse peategelasega, kolmandaks aitab tegelasekesksusele kaasa ka iseenda kujutamine sündmuste osalisena. Esialgse hüpoteesina võibki siis arvata, et eesti proosa murdekasutuse erinevaid võimalusi ühendab kõige rohkem „tegelase hääl”. Seejuures esindavad Lattik ja Schmalz omas ajas kahte peamist lahendust kõige stiilipuhtamalt.

\section{Lõpetuseks}

XIX sajandi lõpu ja XX sajandi alguse proosakirjanduse lähem vaatlus annab kinnituse, et murrete kasutamine proosas kujuneb omaette nähtuseks. Siin on võimalik märgata kirjandusloolist lainet, mis kujundab välja kindlad - ja tollel hetkel eesti kirjanduse jaoks uued - tavad, kuidas murdekasutus peaks toimima. Lattikut ja Schmalzi sai nimetatud kahe peamise lahenduse esindajateks, on aga kindel, et Lattikule iseloomulikud võtted saavad eesti kirjanduses tüüpilisemaks. Edaspidigi kasutatakse murret ennekõike otsekõnes ja murdelisi tsitaate jutustajatekstis. Murre jääb märkima sotsiaalset staatust, haridust ja päritolu, murre elustub mälestustes ning murre elustab huumorit. 
Käsitletud autorite murdekasutus on korraga kollektiivne ja isikupärane. Kitzberg on kõige mitmekesisem, ta tegutseb teerajajana, kes nagu juttude kaupa prooviks läbi erinevaid variante. Lattik on selles seltskonnas kõige järjekindlam ja küllap siis ka edasistele autoritele kõige selgemat eeskuju pakkuv. Enno on kõige tõsisem ja oma müstiliste kalduvuste juures ometi kõige realistlikuma keelega. Schmalz on jällegi kõige selgemalt seotud koomilise traditsiooniga ning kasutab murret mitte ainult otsekõnes, vaid ka mujal.

Need neli kirjanikku on pärit Lõuna-Eestist. Kas lõunaeestikeelne kirjutamine erineb ka ülejäänud murdekirjandusest? Praeguse materjalihulga pealt ei saa lõpuni kindlaid vastuseid anda, aga võib oletada, et kui ka üldreeglid on sarnased, siis lounaeesti murrete selgem eristumine teistest eesti keele variantidest on tekitanud lounaeestikeelses kirjanduses selliseid jooni, mida mujal ei ole. On võimalik, et tava tsiteerida murret jutustajatekstis on lõunaeestiline erijoon - aga seda hüpoteesi peaks juba järgnevates uurimustes kontrollima.

Murdeid kasutatakse eesti kirjanduses ka pärast 1910. aastat ning on arutamist väärt, kuidas siin Kitzbergi, Lattiku, Enno ja Schmalzi kirjutatu välja paistab. Kas Oskar Lutsu „Kevade” oleks ikka just sellisena ilmunud, kui varem poleks ilmunud Lattiku jutte? Kas keelte segamine ja sellega mängimine ulatub mõjutama lõunaeestilist avangardi kümmekond aastat hiljem? Kas XX ja XXI sajandi vahetuse setu proosa taastumine toetub Schmalzi traditsioonidele või millelegi muule? Selliseid küsimusi saab küsida ja võimalik, et ka mõnele küsimusele vastuse leida.

Üks küsimus teiste seas on ka see, miks siin artiklis käsitletud nähtust pole varem sellisel viisil kirjeldatud. Sellel paistab esialgu olevat kaks omavahel seotud vastust. Esiteks võiks arvata, et kui ei ole kirjeldatud seda nähtust, siis on kirjeldatud midagi muud ning valik on sõltunud kasutusel olnud alusskeemidest. Kirjandusloos on korduvalt räägitud järelärkamisaegsest seisakust, venestamise halvavast mõjust, realismi tulekust eesti kirjandusse, realismi vastandumisest vanaaegsele romantikale, aga teiselt poolt vastandumist ka tekkivale uusromantikale. Nende tähtsate teemade juures pole küllap tähtsaks peetud seda, mida siinkirjutajad tähtsaks pidasid. Teiseks võiks tähele panna ka seda, et siin käsitletud autorid või tekstid on olnud pikka aega alahinnatud ning see on mõjutanud nende saatust. Kitzberg saavutas küll klassiku staatuse varakult, kuid tema proosatekste on enamasti peetud näidendite kõrval teisejärgulisteks ning neist on vähe kirjutatud. Olulist rolli mängib ka nooreestlaste ja nende vaateid jaganud kriitikute arvamus, mis vastandus uue esteetika kuulutamisel kõigele, mis moodsa kirjutamisviisiga kokku ei tahtnud kõlada. Teistest kergemini pääses Kitzberg, kuid ka tema proosa satub (eriti draamakirjanduse taustal) nooreestilikus käsitluses ambivalentsesse valgusse (vt nt Tuglas 1915). Aino Kallase arvates polnud Lattiku esimeses raamatus mitte ühtegi kunstitööd (Kallas 1908: 145). Bernhard Linde arvustus raamatule „Meie noored” on leebem, aga kui ta lõpuks jõuab juttude häid ja halbu külgi välja tuues selleni, et Lattik võiks tulevikus midagi rohkem pakkuda (Linde 1908), siis võib aru saada, et meistriteosest siin arvustaja arvates jutt ei käinud. Grünthal (1910) ja, eriti Tuglas (1911) on väga kriitilised Enno proosa suhtes. See määras ilmselt pikkadeks aastateks suhtumise raamatusse „Minu sõbrad”. Praegu ei pea me Tuglase hinnangutega nõus olema. Aga meil on siiski meeldiv võimalus nõus olla sellega, mida ta ütleb 
Lattiku ja Enno kohta arvustuse viimaste sõnadega: „...nad harjutavad ka omalt poolt lugejaid sellega, et kirjakeele kui viimase pühaduse peale ei tarvitse vaadata, et see end murda lubab ja et seda tarvis on murda" (Tuglas 1911: 37).

\section{Kirjandus}

Aabrams, Vahur 2013. Schmalzi „setoraamatist” kultuuriloolisõl taustal. Töganitsa Höödo, Alatarõ Hipo ja tõsõ’ Hermann Julius Schmalzi juttõ. (Seto kirävara 5.) Värska: Seto Instituut, lk 165-175.

E n n o, Ernst 1910. Minu sõbrad. Tartu: K. Sööt.

Grünthal, Villem 1910. E. Enno. Minu sõbrad. - Postimees 13. XI (26. XI), nr $259,1 \mathrm{k} 1$.

Hennoste, Tiit 2000. Eesti kirjanduse keelest modernismi, postmodernismi ja postkolonialismi taustal. - Vikerkaar, nr 7, lk 69-79.

Hennoste, Tiit, Paju salu, Karl 2009. Murre ilukirjanduses. - Karl Pajusalu, Tiit Hennoste, Ellen Niit, Peeter Päll, Jüri Viikberg, Eesti murded ja kohanimed. 2., täiendatud trükk. Toim T. Hennoste. Tallinn: Eesti Keele Sihtasutus, lk $120-123$.

Hu bel, Eduard 1910 = E. H., E. Enno. Minu sõbrad. - Tallinna Teataja 25. XI (8. XII), nr 237, lk 1.

Kalda, Maie 1996. Makaroonilisi ühe- ja kahekõnesid eesti kultuuriruumis. Looming, nr 2, lk 258-270.

Kall a s, Aino 1908. Jaan Lattik. Meie noored. - Eesti Kirjandus, nr 3, lk 144-146.

Kitzberg, August 1910. E. Enno. „Minu sõbrad”. - Eesti Kirjandus, nr 11, lk 462-463.

Ki t z b e r g, August 1915. Külajutud III. Tartu: Noor-Eesti.

Ki t z b e r g, August 1919. Külajutud II. Tartu: Noor-Eesti.

Kit z ber g, August 1920. Külajutud IV. Tartu: Noor-Eesti.

L a a n e k a s k, Heli 2004. Eesti kirjakeele kujunemine ja kujundamine 16.-19. sajandil. (Dissertationes philologiae Estonicae Universitatis Tartuensis 14.) Tartu: Tartu Ülikooli Kirjastus.

Laigna, Karl 1959. Juhan Kunder. Mitmekülgne kultuuritegelane. Lühimonograafia. (Eesti kirjamehi.) Tallinn: Eesti Riiklik Kirjastus.

Lattik, Jaan [1907]. Meie noored. Tartu: K. Sööt.

Le ech, Geoffrey, Sh ort, Mick 2007. Style in Fiction. A Linguistic Introduction to English Fictional Prose. Second edition. (English Language Series.) Harlow [etc.]: Longman.

Li in d e, Bernhard 1908. Jaan Lattik. Meie noored. - Kirjandus ja teadus. „Õiguse” hinnata kaasanne, $\mathrm{nr} 6$, lk 45.

M a t th e u s, Ave 2015. Lapsepõlvemälestused vanalt Võrumaalt. - Tartu Ülikooli Lõuna-Eesti keele- ja kultuuriuuringute keskuse aastaraamat XIII-XIV (20132014). Toim Mart Velsker, Triin Iva. Tartu: Tartu Ülikool, lk 101-134.

N y k ä n e n, Elise, Ko i v i s t o, Aino 2013. Näkökulmia kaunokirjalliseen dialogiin. - Dialogi kaunokirjallisuudessa. Toim Aino Koivisto, Elise Nykänen. (Tietolipas 242.) Helsinki: Suomalaisen Kirjallisuuden Seura, lk 9-56.

Pe e b o, Jaak 2006. Märkusi dialoogide murdekeele kohta. - Madis Kõiv, Näidendid I. Tartu: Akkon, lk 266-267. 
S a a r, Evar 1998. Ka murdekeel väärib toimetamist. - Sirp 13. XI, nr 43, lk 7.

Sa areste, Andrus 1955. Petit atlas des parlers estoniens. Väike eesti murdeatlas. (Skrifter utgivna av Kungl. Gustav Adolfs Akademien 28. Travaux publiés par l'Académie Royale Gustave Adolphe 28.) Uppsala.

Schmalz, Hermann Julius 1901. Alatarõ Hippo Peterbuura reis ja imelik unõnägo inne toda. Tartu: Hermann.

[Sch malz, Hermann Julius] 1906. Miä tõmokraat tähendäs? Tartu: Schnakenburg.

[S ch m a l z, Hermann Julius] 1912. Tölpsaarõ Andre ja Lükova Ivvani kokkosaamine Jurjovah üle hulga ajo. Tartu: Hermann.

Tiittula, Liisa, Nuolijärvi, Pirkko 2013. Puheen illuusio suomalaisessa kaunokirjallisuudessa. (Suomalaisen Kirjallisuuden Seuran toimituksia 1401.) Helsinki: SKS.

Tóth, Szilárd 2013. Täpsustusi eesti kirjakeele viienda perioodi (1857-1905) hääbuva tartukeelse kirjasõna kohta. - Tartu Ülikooli Lõuna-Eesti keele- ja kultuuriuuringute keskuse aastaraamat XI-XII (2011-2012). Toim Mari Mets, Karl Pajusalu. Tartu: Tartu Ülikool, lk 84-92.

Tu gl a s, Friedebert 1911. E. Enno. Minu sõbrad. - Eesti Kirjandus, nr 1, lk 32-37.

Tuglas, Friedebert 1915. August Kitzberg jutukirjanikuna. 60-aastase sünnipäeva puhul. - Pealinna Teataja 25. XII (7. XII), nr 300 (324), lk 3-4; Pealinna Teataja 29. XII (11. XII), nr 301 (325), lk 2-3; Pealinna Teataja 30. XII (12. XII), nr 302 (326), lk 2.

Vels k e r, Mart 2015. Obinitsast Hiiumaa rannale. - Looming, nr 8, lk 1174-1188.

W ales, Katie 2001. A Dictionary of Stylistics. Second edition. (Studies in Language and Linguistics.) Harlow [etc.]: Longman.

\section{Return of the South Estonian language into literary prose}

Keywords: August Kitzberg, Jaan Lattik, Ernst Enno, Hermann Julius Schmalz, Estonian prose, South Estonian, dialects, language in literature

Although the turn of the $20^{\text {th }}$ century marked a retreat of the South Estonian literary language, also called Tartu language, from the printed word, the period brought some new ways to use dialects in fiction. The most prominent users of South Estonian dialects in the prose of the time were August Kitzberg, Jaan Lattik, Ernst Enno and Hermann Julius Schmalz, which makes the four authors responsible for bringing South Estonian back to literature.

Kitzberg, who was the first of the four to start his literary career, offers various solutions. Nevertheless, his oeuvre demonstrates all those techniques regarded as typical of the literary use of dialects. The Mulgi dialect as used by Kitzberg mainly occurs in direct speech, providing cues of social status, education and background, often serving as a comic device. However, Kitzberg can as well be found using dialect speech in a serious text, without an emphasis on differences in social status.

With Lattik, dialect use serves a mild comical effect, being avoided in more serious narratives. Võru dialect usually occurs in his memoir-based prose as direct speech uttered by persons of a lower social status or by uneducated people (often children).

Enno also wrote sketches largely based on personal experience, using dialect in direct speech, but his use of the dialect is more natural than that of the rest. Enno 
has considered Tartu dialect eligible for serious texts as well, while the language of his characters is individualised. Here, too, there is some consideration of social status and education, but these were also reflected in normal communicative situations of the early $20^{\text {th }}$ century.

As for the prose by Schmalz it contains dialect speech all the way through, both in direct and reported speech, which is not really typical of the period in question. What is typical, though, is his attempt to add comedy to his stories (standing out for their first intent of being funny) by using Setu dialect.

The dialect use of the above four authors was groundbreaking for the time. The $20^{\text {th }}$ century favoured Lattik' approach, especially concerning the use of dialects in direct speech. Completely South Estonian texts did not start appearing again until the late $20^{\text {th }}$ century. However, the stories by Kitzberg and Enno remain an early evidence of the diversity of literary options for dialect speech.

Eva Velsker (b. 1969), MA, University of Tartu, Lecturer in Estonian Language, eva.velsker@ut.ee

Mart Velsker (b. 1966), PhD, University of Tartu, Lecturer in Estonian Literature, mart.velsker@ut.ee 